Scoones, I. et al. (2013). The politics of evidence: A response to Rulli and D'Odorico. The Journal of Peasant Studies, 40 (5): 911-912 http://dx.doi.org/10.1080/03066150.2013.853045

\title{
The politics of evidence: A response to Rulli and D'Odorico
}

\author{
Ian Scoones, Ruth Hall, Saturnino M. Borras Jr, Ben White \& Wendy Wolford
}

We welcome Rulli and D'Odorico's response to our introduction to the Journal for Peasant Studies (JPS) Forum on Global Land Grabbing (Scoones et al. 2013) in which we discussed the 'literature rush' that has accompanied the global 'land rush'. We outlined a series of concerns with the data being used in this literature - concerns both with the data itself and with its uncritical deployment in popular and academic studies. We called for a second phase of land grab research that would ground abstract calculations of imprecise global averages in favour of concrete, situated and transparent research that could address critical questions such as what is actually happening, who is winning and losing, and why. With our discussion of the 'politics of evidence' we called for research that would extend beyond the fixation on 'killer facts' - the headline-grabbing numbers. Instead, ground-truthing and generating traceable datasets are essential.

Rulli and D'Odorico (2013) do not express any disagreement with these points. Rather, they object to a short section on the role of data that references a criticism of their work made by Fred Pearce in The New Scientist (2013). Marc Edelman also referenced this criticism in his article for the same Forum (Edelman 2013). Fred Pearce's criticisms of Rulli et al. (2013) are cited twice in the same Forum because we considered them important. The primary objection raised by Pearce, with which we agree, was that although Rulli et al. published their article in one of the most well-respected sources for scientific publications in the English-speaking world, they did not go far enough in stressing how problematic their data were. They did not provide a definition of what constitutes a land grab, and their discussion of data was confined to a short note on methods at the end of the article. Rulli et al. then based a new set of calculations on this data and appeared to estimate global water grabbing to a level of precision astounding for such variable and uncertain local events as rainfall, crop production and irrigation. True, Rulli et al. use the term 'scenario', which is, as they point out in their comment, a valid strategy for evaluating potential outcomes, but the term 'scenario' is only applied to the choice of irrigation strategy (no irrigation, irrigation at the same rate as the rest of the country, and irrigation rates that maximize crop production) and not to several other elements that are also 'scenarios': whether the data for land grabbing are accurate, whether the land will be put to production, or what sort of crops/livestock will be produced, and under what production practices. Selecting country data from several flawed datasets and combining them to derive global totals from which to estimate the water being 'grabbed' ratchets up the uncertainty - this was the point of our critique. 
We are very sympathetic to Rulli et al.'s (2013) aims. Their paper has come under particular scrutiny because, unlike the land grab data and summaries produced over the past few years by GRAIN and the Land Matrix, which explicitly state the political nature of their work, Rulli et al.'s work was published in a premier scientific journal. In a debate where the global estimates range so widely, and include reported deals, confirmed deals, deals under negotiation and cancelled deals, all data are subject to real politics in their use and presentation. We suggest that in presenting their results as more certain and scientifically rigorous than they are (for example, detailing the extent of water grabbing in cubic kilometres by country shown to the fourth decimal point), Rulli et al. $(2013,4)$ give the reader a spurious idea of scientific precision. By glossing over significant local variation, Rulli et al.'s work will be cited regularly by those seeking hard numbers but will not actually enlighten the debate. Locher and Sulle (2013, abstract), based on a detailed scrutiny of estimates of land deals in Tanzania, demonstrate the problems that emerge when untraceable data on areas of land acquired by corporations are aggregated, leading to various flaws "including the "virtual survival" of cancelled land deals "on paper". The consequences, they argue, are 'an unnecessarily blurred picture of the land deal situation in Tanzania, and thus an inadequate basis for related political decisions or social actions and a misleading starting point for new research projects' (Locher and Sulle 2013, 1, emphasis added).

In their original article, Rulli et al. $(2013,2)$ suggest that the lack of good data on landgrabbing is 'inherent to the nature of the problem', and this is indeed our point. Studies derived from this data compound the uncertainty as to the claims being made. We second our call for more in-depth grounded research that can better support global claims and scenarios. We hope that this debate will spur readers and scholars to engage in the next wave of work on the global land grab. 


\section{References}

Edelman, M. 2013. Messy hectares: questions about the epistemology of land grabbing data. Journal of Peasant Studies, 40(3), 485-501.

Locher, M. and E. Sulle. 2013. Foreign land deals in Tanzania: an update and a critical view on the challenges of data (re)production [online]. LDPI Working Paper. Land Deal Politics Initiative, ISS: The Hague, Netherlands. Available from: http://www.iss.nl/fileadmin/ASSETS/iss/Research_and_projects/Research_netw orks/LDPI/LDPI_WP_31_revised.pdf [Accessed 5 August 2013].

Pearce, F. 2013. Splash and grab: the global scramble for water [online]. New Scientist, 4 March. Available from: http://www.newscientist.com/article/mg21729066.400splash-and-grabtheglobal-scramble-for-water.html [Accessed 11 April 2013].

Rulli, M.C., and P. D'Odorico. 2013. The science of evidence: the value of global studies on land rush. Journal of Peasant Studies 4O(5), 10.1080/03066150.2013.853044.

Rulli, M.C., A. Saviori and P. D'Odorico. 2013. Global land and water grabbing. Proceedings of the National Academy of Sciences, 110(3), 892-7.

Scoones, I., et al. 2013. The politics of evidence: methodologies for understanding the global land rush. Journal of Peasant Studies, 40(3), 469-83. 